\title{
Human exclusion from rocky intertidal of Las Cruces, central Chile: effects on Durvillaea antarctica (Phaeophyta, Durvilleales)
}

\author{
Juan C. Castilla, Rodrigo H. Bustamante* \\ Estación Costera de Investigaciones Marinas (ECIM), Departamento de Ecología, Universidad Católica de Chile, Casilla 114-D, \\ Santiago, Chile
}

\begin{abstract}
On the exposed rocky shores of central Chile there exists a continuous small-scale harvesting of bull-kelp Durvillaea antarctica, by 'mariscadores' (shellfish and algae gatherers). These harvest both fronds and stipes for human consumption. To assess the effects of human activity on $D$. antarctica populations, the density, standing crop and size structure of the kelp were compared in nonharvested (fenced) and regularly harvested (unfenced) areas. Both coastal mainland and small islands were included in the fenced and unfenced areas. Unfenced islands were expected to receive less human disturbance than unfenced mainland areas, because the islands were less accessible to harvesters. Populations of kelp underwent great fluctuations in abundance throughout the study period. Comparison between harvested and non-harvested areas revealed significant differences in density, biomass and size structure. In contrast, no significant differences were found between nearshore islands inside and outside the fenced area. Sources of variation in abundance of populations correspond to recruitment, natural mortality and harvesting, especially in harvested mainland areas. Interaction between time and extent of exploitation is significant when $D$. antarctica biomass is considered. The existence of protected areas (coastal preserves) and of areas of difficult access to mariscadores (refuges or 'bufferzones') allows the preservation of populations and facilitates re-population of harvested zones.
\end{abstract}

\section{INTRODUCTION}

The ecological impact of man acting as a top predator on intertidal ecosystems has been evaluated in several studies during the past decade. Research in the southern hemisphere has shown that man has a critical influence on intertidal communities (Branch 1975, Moreno et al. 1984, Castilla \& Durán 1985, Siegfried et al. 1985, Hockey \& Bosman 1986, Moreno et al. 1986, Oliva \& Castilla 1986, Durán et al. 1987). Studies by Castilla \& Durán (1985) and Oliva \& Castilla (1986) have shown that, in central Chile, intertidal harvesting by gatherers substantially modifies the structure and abundance of invertebrate populations. Along the Chilean littoral zone, close to urban centers, there are many small-scale gatherers operating at the subsistence level, locally known as 'mariscadores de orilla' (Durán et al. 1987). During low tides, they harvest a

\footnotetext{
- Present address: Department of Zoology, University of Cape Town, Rondebosch 7700, Cape Town, South Africa
}

great variety of marine invertebrate and algal species, mostly for human consumption.

Most of the above kind of research in Chile has focused on the effects of human predation on keystone species (sensu Paine 1966) of marine invertebrates, particularly gastropods (see Castilla \& Durán 1985, Moreno et al. 1986). However, the mariscadores also collect important algal species from central Chilean rocky shores, such as the bull-kelp Durvillaea antarctica (both fronds and stipes), and the purple laver or 'luche' Porphyra columbia (Guiler 1959, Hay 1977, Santelices et al. 1980, Santelices \& Avila 1985).

In central Chile, the lower fringe of the intertidal rocky shore is usually dominated by a conspicuous belt of 2 brown (Division Phaeophyta) macroalgae: Lessonia nigrescens (Bory) and Durvillaea antarctica (Chamisso). L. nigrescens predominates in cover, number of individuals and biomass (Guiler 1959, Santelices et al. 1977, Santelices et al. 1980, Ojeda \& Santelices 1984). In contrast, in southern Chile, where L. nigrescens is absent, $D$. antarctica forms monocul- 
tures along the lower intertidal fringe (Hay 1977 , 1979b, Dayton 1985, J. C. Castila, pers. obs. in Beagle Channel). A high abundance of $D$. antarctica (in the absence of $L$. nigrescens) has also been recorded at other sites in the southern hemisphere, especially in the sub-antarctic regions (Paine 1971, Hay 1979a, c, Hay \& South 1979,. South \& Hay 1979, Buschmann 1982, Haxen \& Grindley 1985, Lawerence 1986).

Guiler (1959) proposed that on exposed shores of central Chile, preventing human harvesting would result in a change in the outcome of spatial competition between the 2 brown macroalgae, with Durvillaea antarctica showing an enhancement of its populations and in some areas dominating over Lessonia nigrescens. On the other hand, Santelices et al. (1980) concluded that in central Chile the outcome of competition between the 2 phaeophytes is dependent on the degree of wave exposure, their morphological adaptations, and differences in their life history strategies. Hence, $L$. nigrescens emerges as a species that monopolizes primary space in the long term, whereas $D$. antarctica persists only because of its high rate of settlement and rapid growth.

In this paper we evaluate the hypothesis that harvesting of Durvillaea antarctica by mariscadores on exposed rocky shores of central Chile has important consequences for their population biology. Our expectation was that the density, size structure and biomass of bull-kelp populations in the absence of harvesting pressures would be significantly different from those with a continuous harvesting regime. Further, we discuss the concept of 'buffer-zones' (sensu Castilla \&
Schmiede 1979), namely non-harvested areas or sites of difficult access, such as small nearshore islands, that serve as refuges or 'seeding grounds' for $D$. antarctica.

\section{MATERIALS AND METHODS}

Study site. Work was carried out at Las Cruces (Punta El Lacho, $33^{\circ} 30^{\prime} \mathrm{S}, 71^{\circ} 38^{\prime} \mathrm{W}$ ) between 1981 and 1987. The Catholic University of Chile built a Marine Station, 'Estación Costera de Investigaciones Marinas' (ECIM) at this locality in December 1982 (Fig. 1). The station is located on an exposed rocky coastline, with a seafront of about $500 \mathrm{~m}$ and a total intertidal rocky shore area of about $4152 \mathrm{~m}^{2}$ (and $44130 \mathrm{~m}^{2}$ of sea surface and sea bed). Both the ECIM intertidal rocky shore (including small nearshore islands) and the sea bed have been closed to the public, fishermen, and mariscadores since December 1982 (non-harvested area). In contrast, the rocky intertidal areas immediately adjacent to the preserve are intensively harvested (Durán et al. 1987). The easily accessible rocky shore is termed 'Mainland' and the small nearshore islands (less than $100 \mathrm{~m}^{2}$ of surface) opposite the mainland 'Islands'. Work in the harvested areas was conducted outside the north boundary of the preserve. Exposure, substratum heterogeneity and slope (mostly between $45^{\circ}$ and $90^{\circ}$ ) of this area are similar to those of the preserve area. Islands within the preserve (non-harvested) were compared with islands outside the preserve (which are only occasionally harvested, due to their relative inaccessibility).

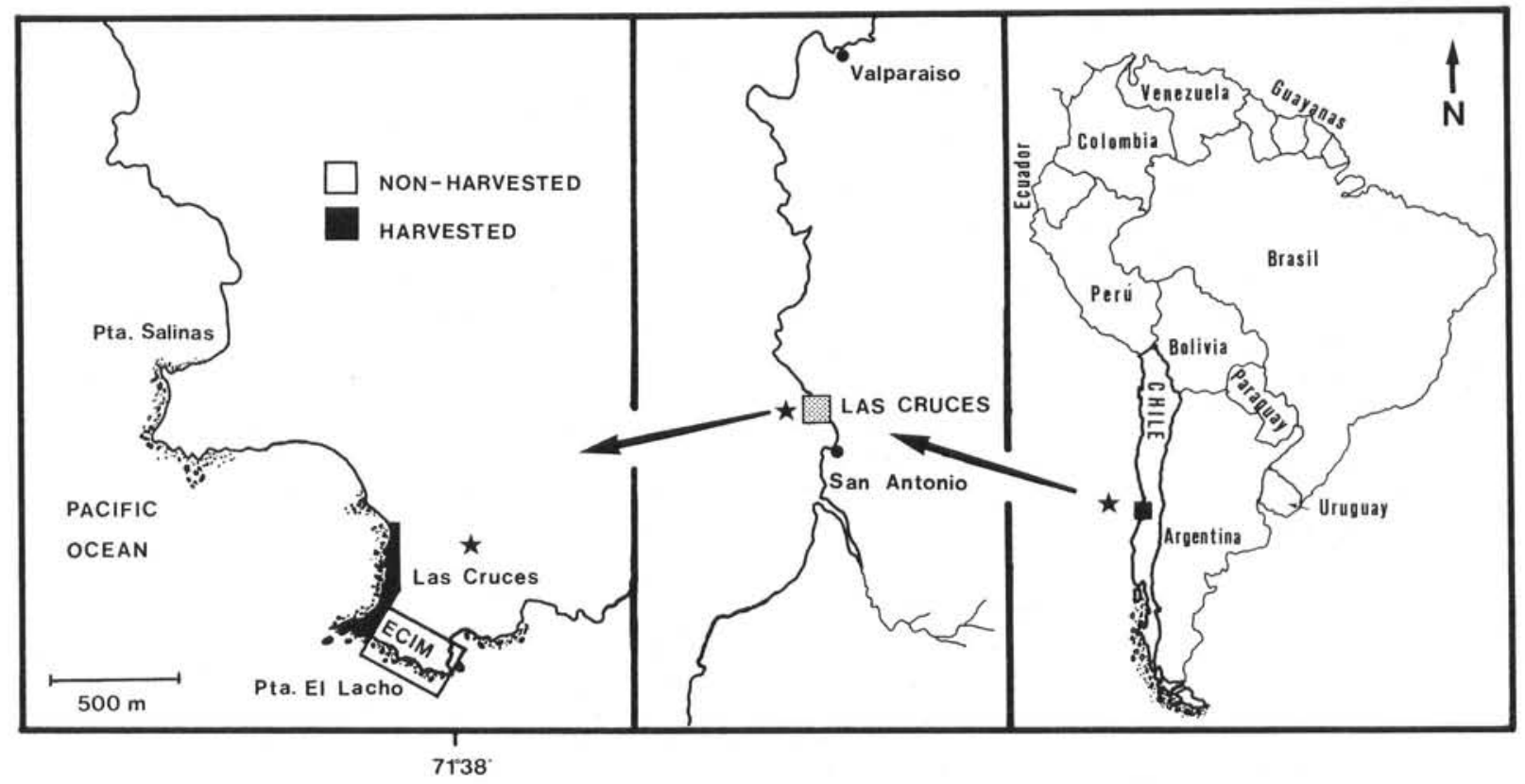

Fig. 1. Durvillaea antarctica. South America and location of Las Cruces, showing ECIM fenced non-harvested rocky shore and adjacent harvested area 
The rock substratum at Las Cruces (harvested and non-harvested sites) consist of a metamorphic gneiss with lamprophytic intrusions (Oliva \& Castilla 1986). Mainland sites are largely exposed to wave impact, with wave forces during summer and winter (January and June to July 1987) of 740 to $1200 \mathrm{~kg}$ per m$^{-2}$ (Ortíz \& Castilla unpubl. using Palumbi's [1984] wave force device). Southwesterly winds predominate during most of the year (Araya-Vergara 1982). The tidal amplitude at spring tides is $1.82 \mathrm{~m}$ (Araya-Vergara 1982, Anonymous 1987).

Sampling. Durvillaea antarctica was monitored during low tides every 6 mo between May 1981 and December 1984, and every 3 mo between March 1985 and March 1987. Sampling areas were 2 zones of ca $500 \mathrm{~m}$ of coastline, one in the preserve and one in the harvested area, each divided alongshore into permanent $50 \mathrm{~m}$ transects, 6 of which were initially randomly chosen for sampling. Between March 1985 and March 1987, a group of small islands within and another outside the fenced ECIM area were sampled every 3 mo as described above. At both types of habitats (mainland and islands) $50 \mathrm{~m}$ transects were set parallel to the sea border, within the area occupied by the belt formed by Lessonia nigrescens (Bory) and Durvillaea antarctica (Chamisso), and were sampled at the lower intertidal fringe (Castilla 1981). Data taken during these sampling periods included number of plants, sizes of

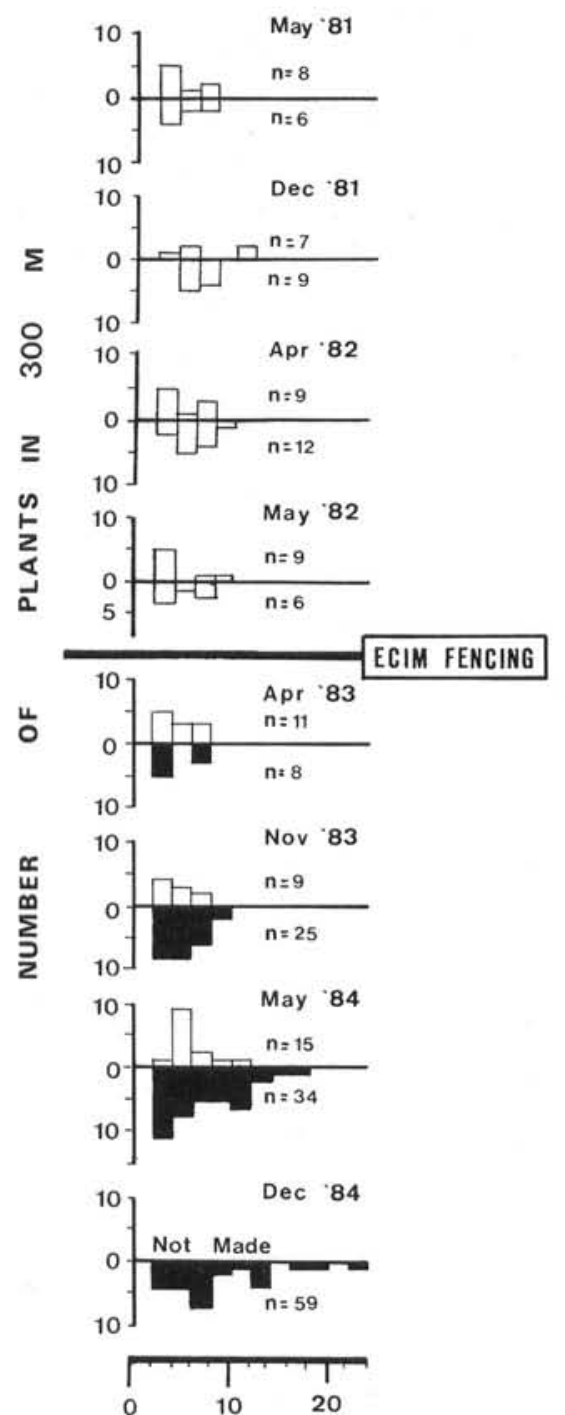

MAXIMUM
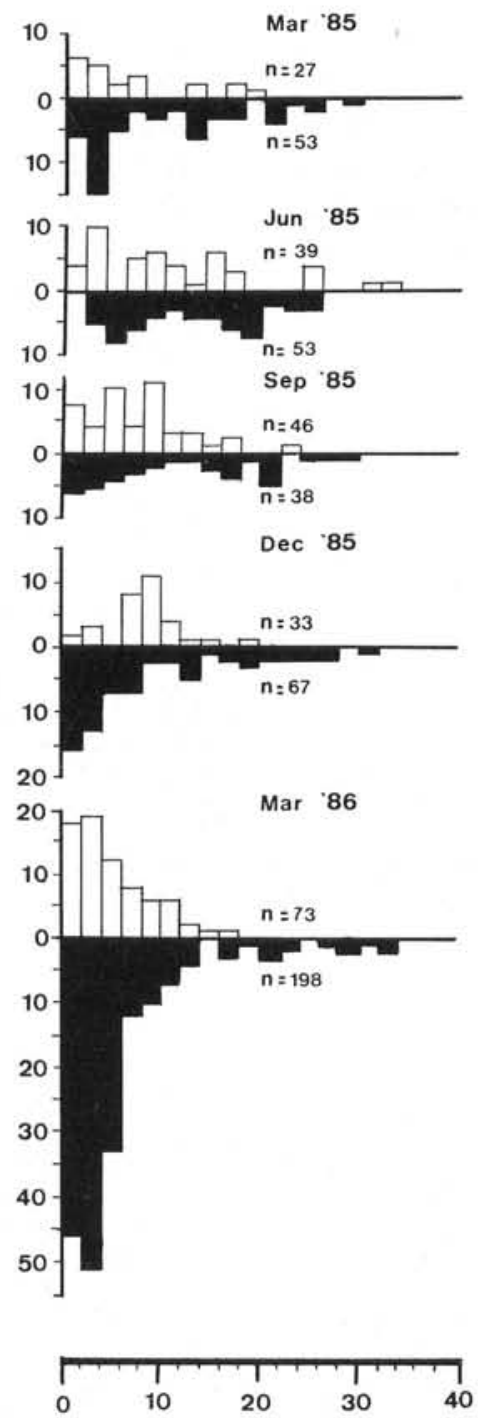

DIAMETER OF HOLDFAST
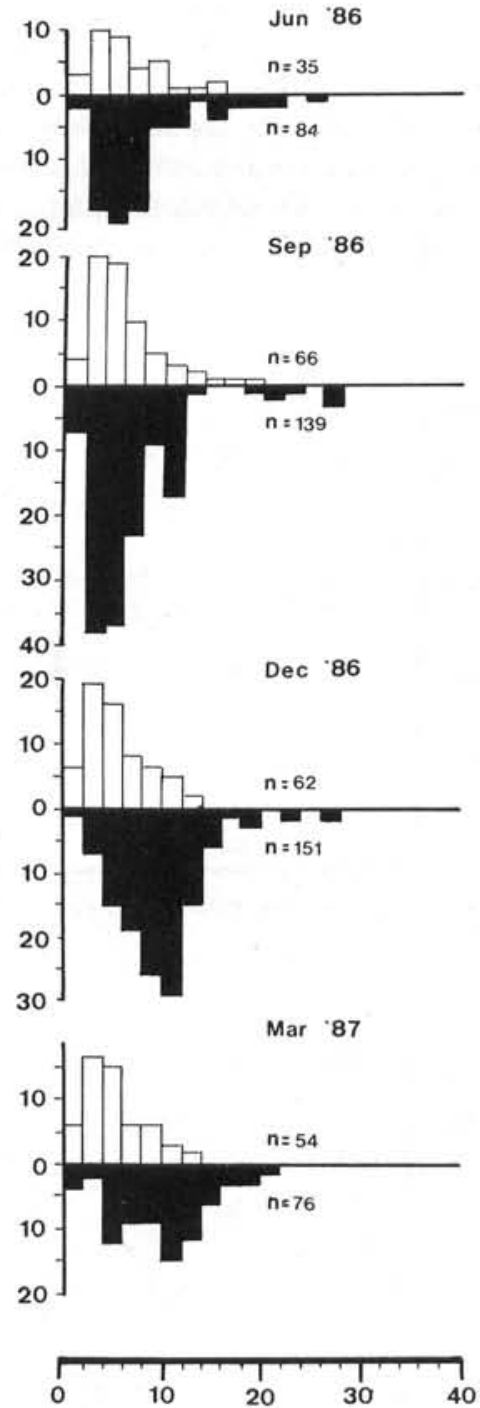

(CM)

Fig. 2. Durvillaea antarctica. Number of plants and size structure (diameter of holdfast) between May 1981 and March 1987 on Las Cruces mainland. Open bars: harvested; black bars: non-harvested. Histograms above the line are those that are outside ECIM and were initially available to mariscadores, until the fence was erected 
individual $D$. antarctica plants, and mean width of kelp belt.

Morphometric wet weight relations. To provide regression data and avoid destructive sampling at ECIM, 88 non-coalescent plants of Durvillaea antarctica were removed from 3 nearby localities in central Chile (between $32^{\circ} 40^{\prime} \mathrm{S}$ and $33^{\circ} 45^{\prime} \mathrm{S}$ ) excluding Las Cruces. Maximum diameter of holdfast (DH), maximum stipe diameter (SDI), maximum frond length (LF) and total wet weight (WW) were measured. The plants ranged between 1 and $36 \mathrm{~cm}$ in maximum holdfast diameter. The main morphometric relations between these measures, especially the relation size/wet weight, were assessed by regression analysis. Size structures were evaluated by using the maximum diameter of the holdfast. Individual plants of $D$. antarctica often fuse with each other to form a composite holdfast mass. This phenomenon is known as coalescence of holdfasts (Hay 1977, Santelices et al. 1980). In the study area, coalescence of holdfasts was detected in only $5.5 \%$ of the individual plants sampled $(\overline{\mathrm{x}}=3.35$, $\mathrm{CV}=1.88 \%$ ).
Harvested versus non-harvested sites. The mainland shores adjacent to ECIM, and accessible to mariscadores, were considered as harvested areas; those sites within ECIM were considered to be non-harvested areas. In the statistical analyses performed (Factorial ANOVA design) these were taken as a 'Degree of Exploitation' variable. The mainland and the islands were recognized as different habitats for Durvillaea antarctica, and were expressed as the 'Habitat' variable. The number of plants and maximum diameter of the holdfast (accuracy to $0.5 \mathrm{~cm}$ ) of each plant within every transect were measured. On rare occasions $(<3.5 \%$ of sampling days) when rough sea conditions precluded measuring the diameter of the plants, the maximum length of fronds was estimated visually and the weight of the plants was estimated from regressions (see 'Results'). The distribution of the number of plants, as well as the distribution of total biomass in harvested and non-harvested sites, were compared by the Smirnov 1-tailed test (Conover 1980). The frequencies of plants present on mainland and islands and inside and outside ECIM were compared on a monthly basis,

A
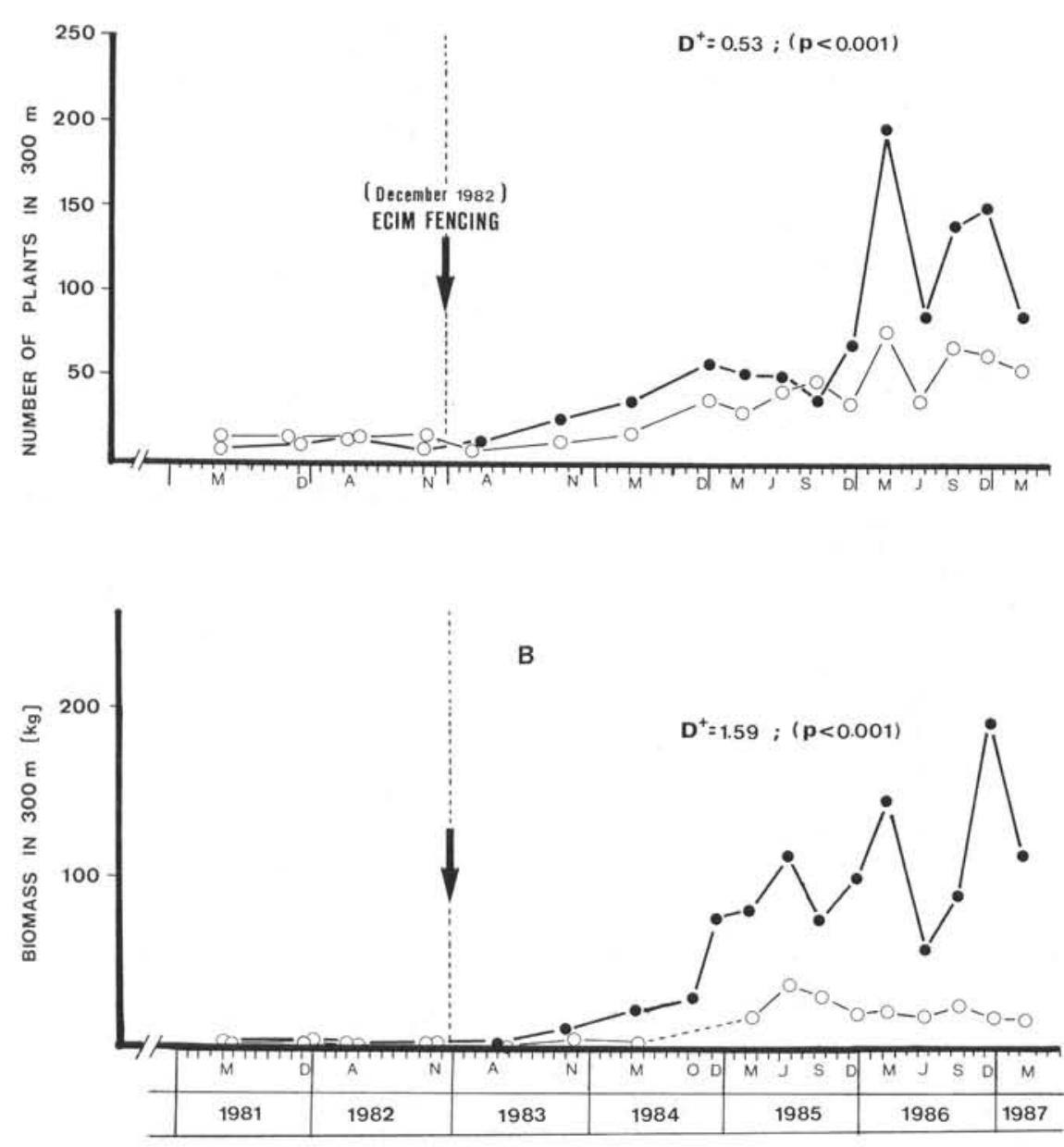

Fig. 3. Durvillaea antarctica. (A) Total number of plants and (B) total biomass in two $300 \mathrm{~m}$ stretches of Las Cruces mainland shores (1981 to 1987). (○- ) Harvested area; $\bullet \bullet$ non-harvested area. $\mathrm{D}^{+}$: Smirnov 1-tailed statistic 
using Fisher's Exact test (Sokal \& Rohlf 1981). Mean diameter and mean wet weight of plants were compared by degree of exploitation and type of habitat, using Tukey's Studentized Range test. The significance of the variables of time, degree of exploitation, habitat and interactions between these variables was tested through a factorial ANOVA, using the individual size and weight of the plants as dependent variables. SAS (Statistical Analysis System 1986) programs were run on a VAX 8600 computer.

In order to estimate the total sampled area, the width of Lessonia nigrescens belts were measured at the harvested and nonharvested rocky shores at least in 10 randomly chosen points. The mean width obtained was then multiplied by the total transect length $(300 \mathrm{~m})$; the resulting area was considered as the potential zone where Durvillaea antarctica could settle. Densities (no. $\mathrm{m}^{-2}$ ) and standing crops $\left(\mathrm{kg} \mathrm{m}^{-2}\right)$ were then calculated for mainland and island shores. Mean density and mean standing crop were compared for the whole period studied, using a 1-way ANOVA by ranks (Conover 1980).

\section{RESULTS}

\section{Morphometric wet weight relations}

The main morphometric and weight relations for 88 plants of Durvillaea antarctica are described by Eqs. (1) and (2). The relation between maximum diameter of the holdfast, DH $(\mathrm{cm})$, and the length of the frond, LF $(\mathrm{cm})$, was:

$$
\mathrm{LF}=10.6723 \mathrm{DH}^{1.1787} ; r^{2}=0.92(p<0.001)
$$

The relation between maximum diameter of holdfast, $\mathrm{DH}(\mathrm{cm})$, and wet weight, WW $(\mathrm{kg})$, was:

$$
\mathrm{WW}=0.0021 \mathrm{DH}^{2.5119} ; r^{2}=0.95(p<0.001)
$$

\section{Mainland rocky shore: non-harvested versus har- vested areas}

Fig. 2 shows the general pattern of changes in number and size structure (maximum holdfast diame-
Fig. 4. Durvillaea antarctica. (A) Density and (B) standing crop on Las Cruces mainland (1985 to 1987). (०—) Harvested area; $(\bullet \bullet)$ non-harvested area (F: 1-way ANOVA)
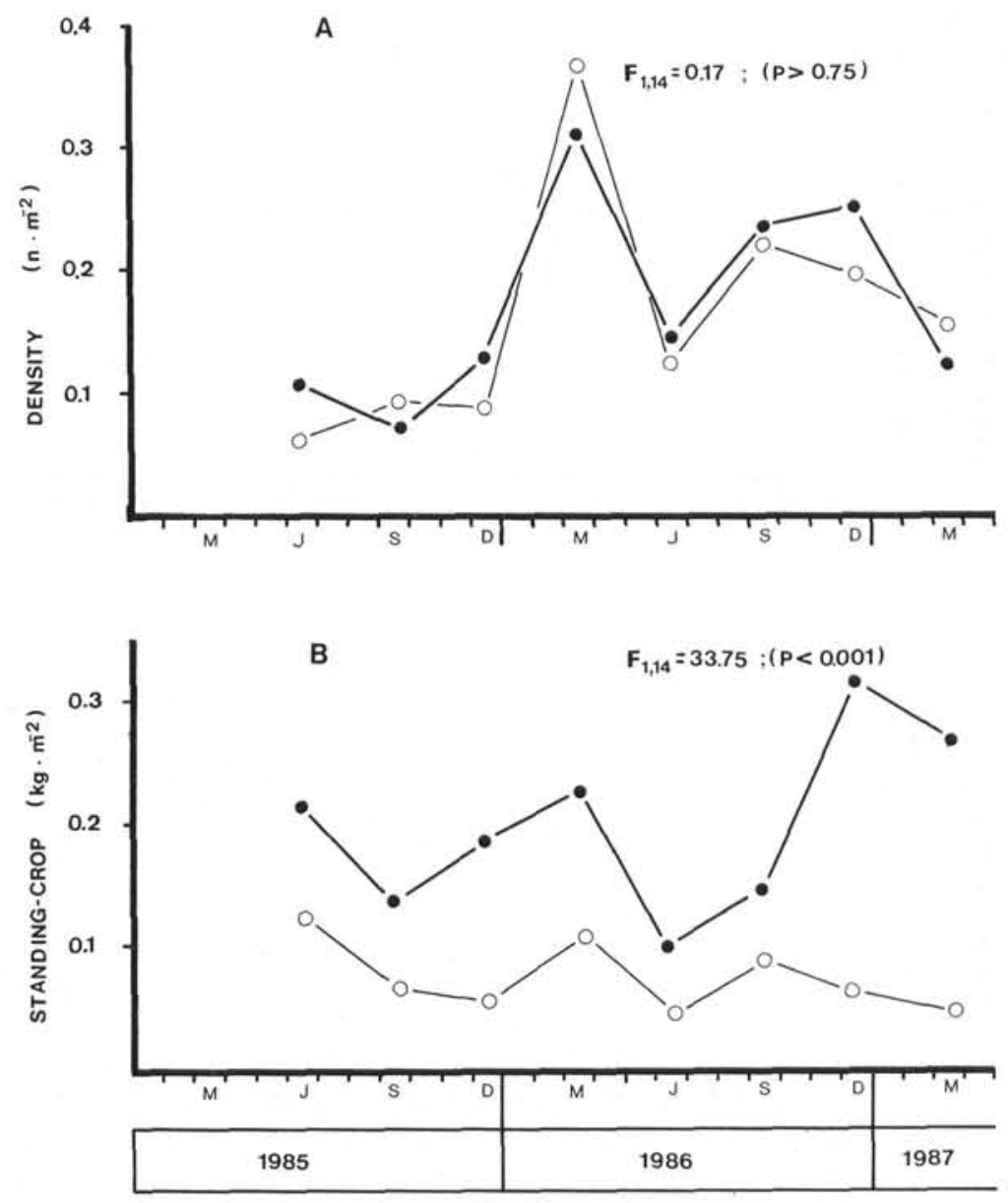
ter) of Durvillaea antarctica at harvested and nonharvested sites at Las Cruces throughout ca $7 \mathrm{yr}$. Dramatic modifications can be observed. Indeed, before the fencing of the ECIM area (e.g. in 1981 and 1982) the number of bull-kelp plants was comparatively low (6 to 12 plants in the $300 \mathrm{~m}$ ) inside and outside of ECIM (at that time both areas were heavily harvested by local mariscadores; Durán et al. 1987). The first census of $D$. antarctica in the non-harvested area of ECIM was made in April 1983. Important changes occurred 17 mo after the fencing (May 1984). A large disparity in the number and sizes of plants at the non-harvested $(n=34)$ versus harvested $(n=15)$ shores was observed. This pattern persisted through 1987. However, the number and size of plants showed dramatic increases in both areas. The latter is particularly striking in the case of young plants. In March 1987 a considerable decrease in the number and size of plants was observed due to removal of large and older plants by southerly storms.

Basic data on Durvillaea antarctica censuses contained in Fig. 2 are further analyzed in Fig. 3, which shows a persistent increases in the total number of plants and their biomass (Figs. 3A, B, respectively). There are significant differences (Smirnov 1-tailed test, $p<0.001$ ), both in number of plants and in biomass, between non-harvested and harvested areas. Further, if the width of the band of Lessonia nigrescens in both sites is considered as the potential zone where $D$. antarctica can live, the density and standing crop per $\mathrm{m}^{2}$ can be estimated (Fig. 4A, B). A comparison of the mean density of bull-kelp plants did not show differences between the 2 areas $(F=0.17, p>0.75)$. In contrast, mean standing crop did show significant differences $(F=33.72, p<0.001)$. Further, Fig. $5 \mathrm{~A}$ depicts the curves for mean plant size (DH) and mean plant wet weight (Fig. 5B), calculated according to Eq. (1), during the monitoring period.

A Tukey's Studentized Range (HSD) test was used to establish differences between pairs of means with different degrees of exploitation. As shown in Fig. 5A, $\mathrm{B}$, significant differences $(p<0.05)$ were found between harvested and non-harvested sites, in both cases about $17 \mathrm{mo}$ after the fencing of ECIM. It is interesting to note that a time lag of about 12 to $18 \mathrm{mo}$ was observed for the increase of plant size and biomass

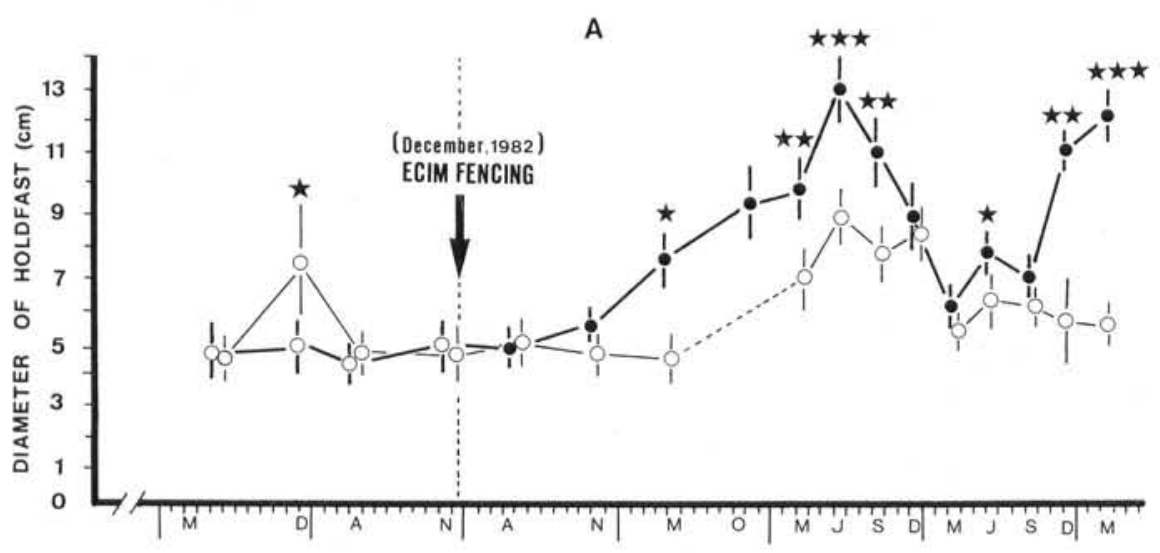

B

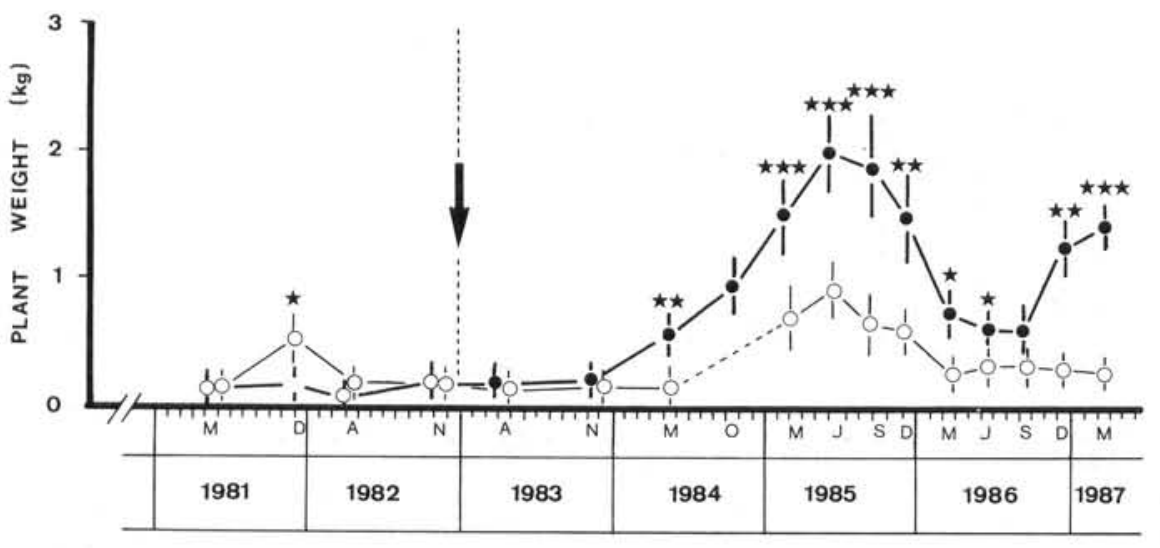

Fig. 5. Durvillaea antarctica. Mean ( $\pm 1 \mathrm{SE}$ ) (A) holdfast diameter and (B) plant wet weight throughout the monitoring period (1981 to 1987 ), before and after the ECIM fencing on mainland shores. $(0-0)$ Harvested area; (- $\bullet$ non-harvested area. (Tukey's Studentized Range test, $\cdots p<0.001, \cdots p<0.01, \cdot p<0.05)$ 
in the harvested area. The maximum values of biomass and plant size found during June to September 1985 were followed in both areas by a steep decrease during the last months of 1985 and early 1986: in March 1986 there were no significant differences in plant size between the 2 areas. A new increase (Fig. 5A, B) in the non-harvested area, but not in the harvested area, was observed in 1987 and, once again, differences between harvested and non-harvested sites became highly significant.

\section{Islands}

Fig. 6 shows the general patterns of distribution of plant size on the islands; these were similar at both sites. Fig. 7 shows the total number (Fig. 7A) and biomass (Fig. 7B) of bull-kelp plants on islands throughout the study period calculated according to Eq. (1). There were no significant differences between the total number of plants at the 2 sites (Fig. 7A, Smirnow 1tailed test, $p>0.1$ ). However significant differences ( $p$ $<0.001$ ) did appear when total biomasses were compared between the 2 types of islands: they were usually greater on islands inside the ECIM area. However, since the width of the Lessonia nigrescens band at the islands was considered as representing the potential intertidal area where Durvillaea antarctica may live, the density and standing crop were calculated for both sites per $\mathrm{m}^{2}$ (Fig. 8A, B). The ANOVA by ranks test revealed no significant differences between islands inside and outside ECIM $(F=0.86, p>0.25$ for density and $F=0.70, p>0.25$ for the standing crop). Fig. $9 \mathrm{~A}$ shows the mean plant size (DH) and Fig. 9B shows the mean individual wet weight (WW) of plants on islands,
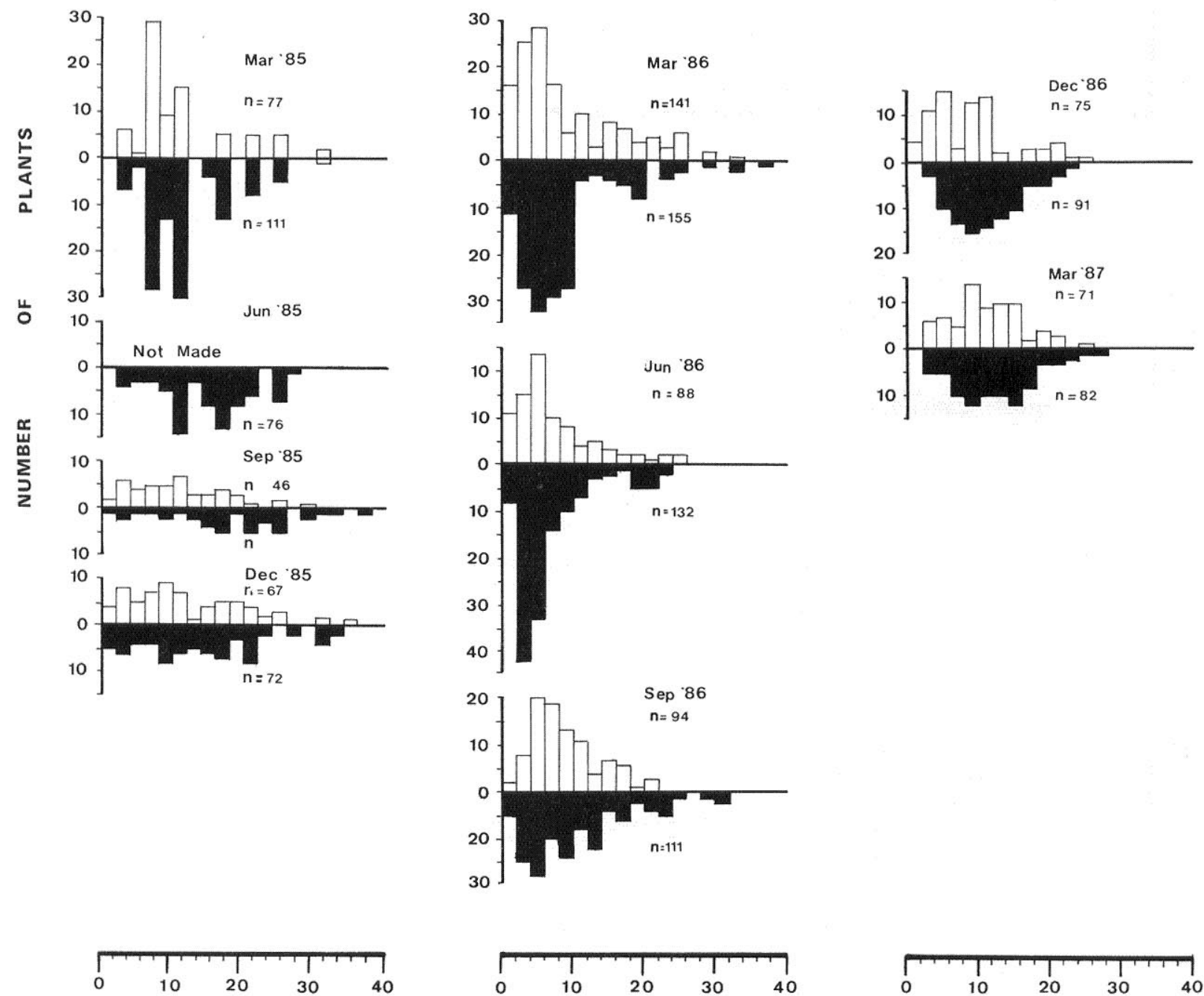

MAXIMUM DIAMETER

OF

HOLDFAST

( CM)

Fig. 6. Durvillaea antarctica. Number and size structure (maximum diameter of holdfast) in the intertidal rocky shore of small islands at Las Cruces, between March 1985 and March 1987. Open bars: islands outside ECIM; black bars: islands inside ECIM 

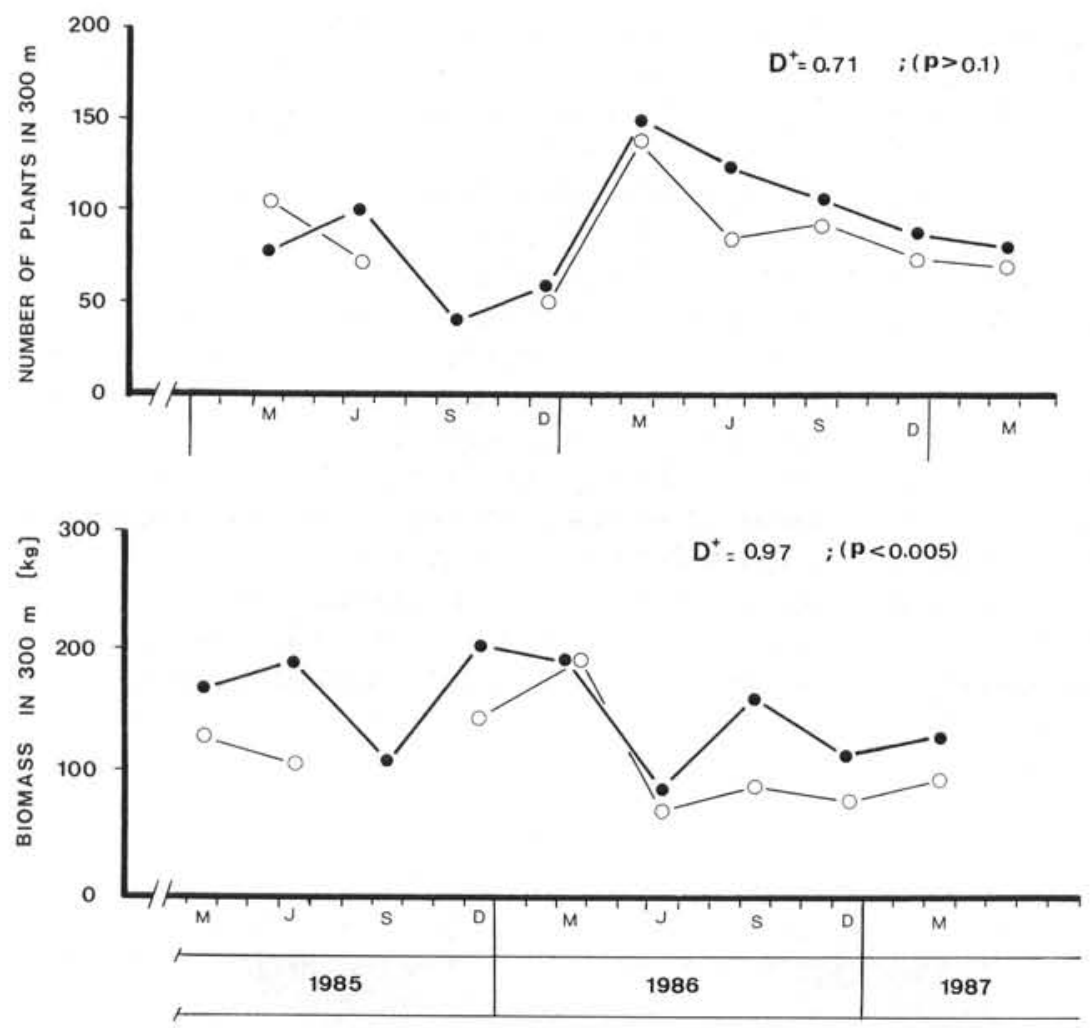

Fig. 7. Durvillaea antarctica. (A) Total number of plants and (B) total biomass in two $300 \mathrm{~m}$ stretches of the intertidal rocky shore of small islands at Las Cruces, between March 1985 and March 1987.

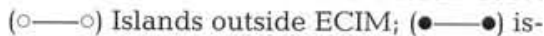
lands inside ECIM. $\mathrm{D}^{+}$: Smirnov 1-tailed test
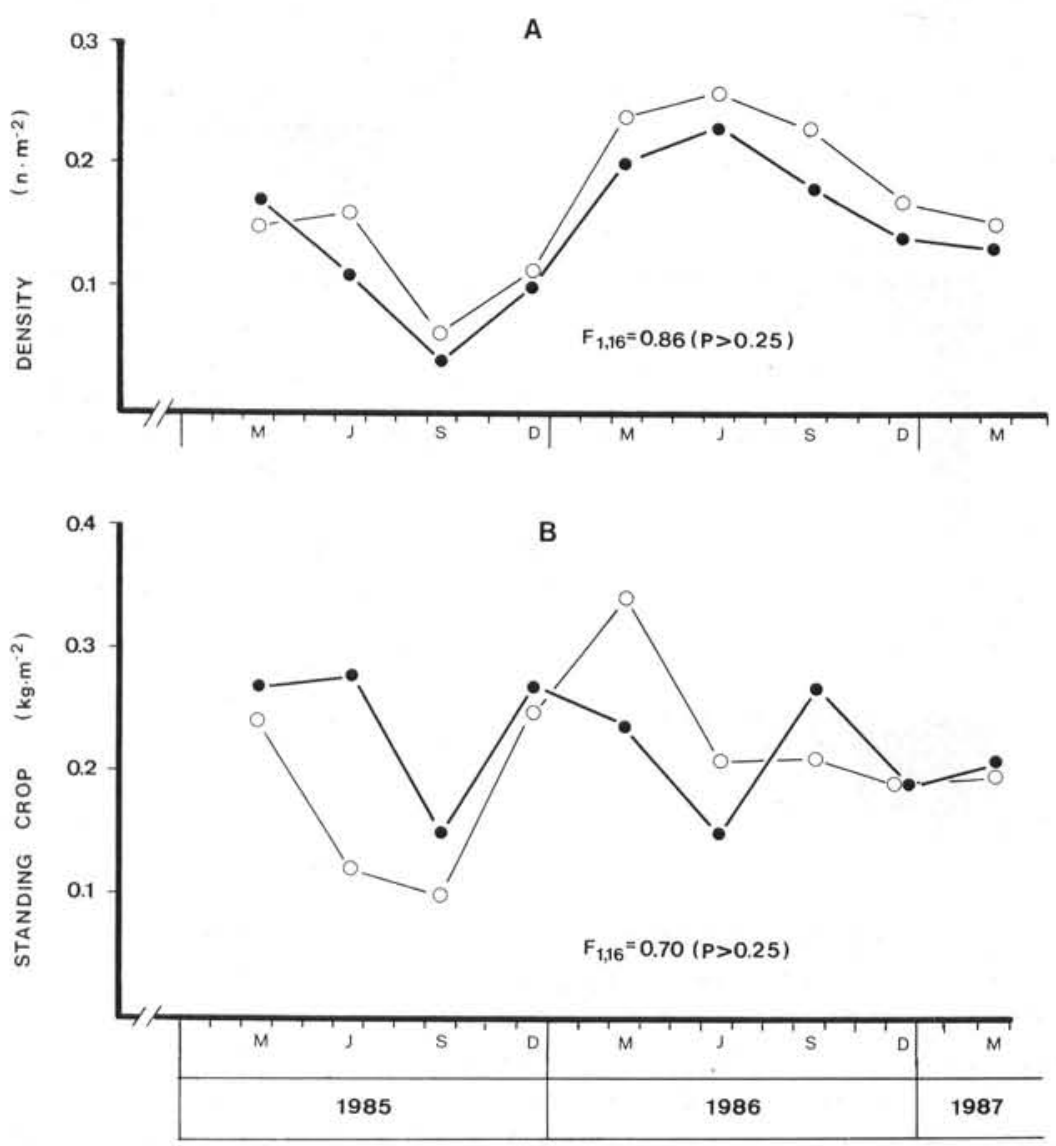

Fig. 8. Durvillaea antarctica. (A) Density and (B) standing crop on small islands in Las Cruces (1985 to 1987). (○-○) Islands outside ECIM; (•-) islands inside ECIM (F: 1-way ANOVA) 


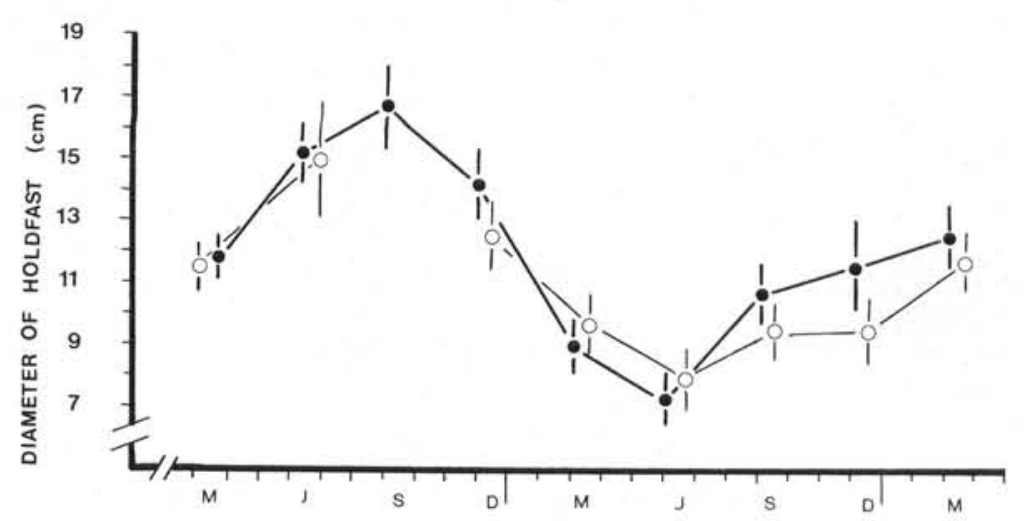

Fig. 9. Durvillaea antarctica. Mean ( $\pm 1 \mathrm{SE})(\mathrm{A})$ holdfast diameter and (B) plant wet weight on exposed islands at Las Cruces (1985 to 1987). $(\bullet-)$ Islands outside ECIM; $(\bullet \bullet)$ islands inside ECIM. (Tukey's Studentized Range test; $\left.\cdots p<0.001, \cdots p<0.01,{ }^{*} p<0.05\right)$

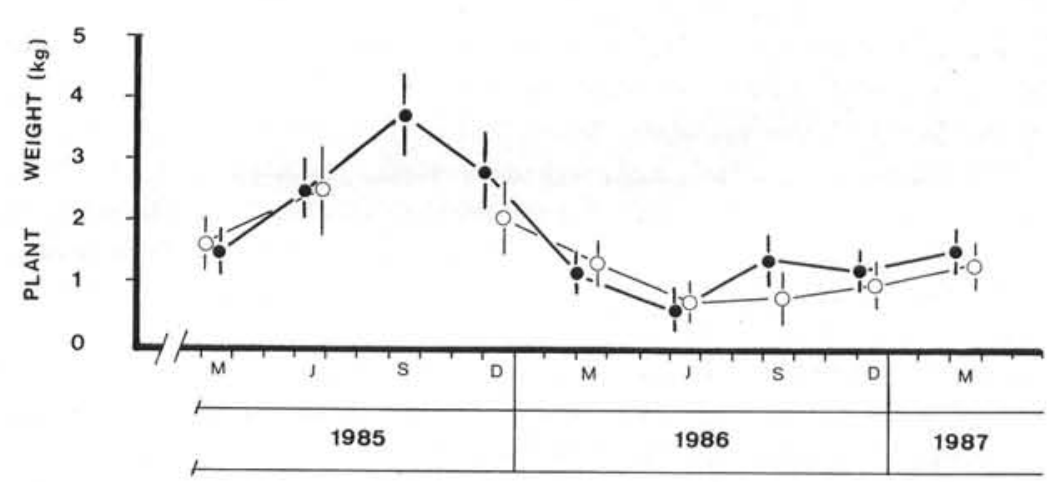

inside and outside the ECIM area. Tukey's test indicates that there are no significant differences $(p>0.05)$ between islands inside and outside ECIM. A pronounced decrease in plant size and biomass was observed in the winter of 1986 (June-July), both inside and outside ECIM. By the end of 1986 and during 1987, an increase in both size and biomass of $D$. antarctica plants was detected.

\section{Multiple comparisons}

Table 1 is a $2 \times 2$ contingency table for the number of plants of Durvillaea antarctica present in non-harvested ('Inside') and harvested ('Outside') areas, in both habitats ('Mainland' and 'Islands'). In March 1985, September 1985, and March 1987, the numbers of plants present inside and outside ECIM were not sig-

Table 1. Durvillaea antarctica. Comparison of the number of plants (absolute frequency) present in the different habitats (Mainland and Islands) between fenced (Inside) and unfenced (Outside) areas, at Las Cruces, using 1-tailed Fisher's Exact test (2 $\times 2$ contingency tables), between March 1985 and March $1987, \cdots p<0.001 ;{ }^{\cdots} p<0.01 ;{ }^{*} p<0.05$; NS: not significant, $p>0.05$

\begin{tabular}{|c|c|c|c|c|c|c|c|c|c|c|}
\hline Month & & Mainland & $\begin{array}{c}1985 \\
\text { Islands }\end{array}$ & $p$ & Mainland & $\begin{array}{c}1986 \\
\text { Islands }\end{array}$ & $p$ & Mainland & $\begin{array}{c}1987 \\
\text { Islands }\end{array}$ & $p$ \\
\hline March & $\begin{array}{l}\text { Inside } \\
\text { Outside }\end{array}$ & $\begin{array}{l}53 \\
27\end{array}$ & $\begin{array}{r}111 \\
77\end{array}$ & $0.166 \mathrm{NS}$ & $\begin{array}{r}198 \\
73\end{array}$ & $\begin{array}{l}155 \\
141\end{array}$ & $0.000 \cdots$ & $\begin{array}{l}76 \\
54\end{array}$ & $\begin{array}{l}82 \\
71\end{array}$ & $0.033 \mathrm{NS}$ \\
\hline June & $\begin{array}{l}\text { Inside } \\
\text { Outside }\end{array}$ & $\begin{array}{l}53 \\
39\end{array}$ & $\begin{array}{l}76 \\
19\end{array}$ & $0.000 \cdots$ & $\begin{array}{l}84 \\
35\end{array}$ & $\begin{array}{r}132 \\
88\end{array}$ & $0.034^{\circ}$ & & & \\
\hline September & $\begin{array}{l}\text { Inside } \\
\text { Outside }\end{array}$ & $\begin{array}{l}38 \\
46\end{array}$ & $\begin{array}{l}37 \\
46\end{array}$ & $0.528 \mathrm{NS}$ & $\begin{array}{r}139 \\
66\end{array}$ & $\begin{array}{r}111 \\
94\end{array}$ & $0.002 \cdots$ & & & \\
\hline December & $\begin{array}{l}\text { Inside } \\
\text { Outside }\end{array}$ & $\begin{array}{l}67 \\
33\end{array}$ & $\begin{array}{l}72 \\
67\end{array}$ & $0.013^{\circ}$ & $\begin{array}{r}151 \\
62\end{array}$ & $\begin{array}{l}91 \\
75\end{array}$ & $0.001 \cdots$ & & & \\
\hline
\end{tabular}


Table 2. Durvillaea antarctica. Significant variables as the result of a factorial ANOVA design, using as dependent variables Size (diameter of holdfast, DH) and Weight (individual wet weight, WW), between March 1985 and March 1987. *.. $p<0.001$; $\cdots p<0.01 ; \cdot p<0.05$; NS: not significant, $p>0.05$

\begin{tabular}{|c|c|c|c|c|c|c|}
\hline \multirow[t]{2}{*}{ Source of variation } & \multicolumn{3}{|c|}{ Diameter of holfast (DH) } & \multicolumn{3}{|c|}{ Wet weight (W) } \\
\hline & df & $F$-value & $p$ & df & $F$-value & $p$ \\
\hline Month & 8 & 12.89 & $0.0001 \cdots$ & 8 & 14.91 & $0.0001 \cdots$ \\
\hline Exploitation & 1 & 20.79 & $0.0001 \cdots$ & 1 & 18.88 & $0.0001 \cdots$ \\
\hline Month $\times$ Expl & 8 & 1.77 & $0.0881 \mathrm{NS}$ & 8 & 2.46 & $0.0158^{\cdots}$ \\
\hline Habitat & 1 & 50.66 & $0.0001 \cdots$ & 1 & 48.79 & $0.0001 \cdots$ \\
\hline Month $\times$ Habitat & 8 & 1.35 & $0.2232 \mathrm{NS}$ & 8 & 1.42 & $0.1907 \mathrm{NS}$ \\
\hline Expl. $\times$ Habitat & 1 & 2.56 & 0.1117 NS & 1 & 2.59 & $0.1095 \mathrm{NS}$ \\
\hline Month $\times$ Expl. $\times$ Habitat & 8 & 1.10 & 0.3678 NS & 8 & 1.17 & $0.3189 \mathrm{NS}$ \\
\hline
\end{tabular}

nificantly different $(p>0.05)$. In the remaining months there were highly significant differences $(p<0.05)$ between the number of bull-kelp plants present inside and outside ECIM in both habitats. Table 2 shows the significance of the variables: months (time), extent of exploitation (harvested and non-harvested), habitat (mainland and islands), and the possible interactions. The most significant variables of the model in order of importance correspond to: month, degree of exploitation, and habitat $(p<0.001)$. The only significant interaction is that between months and degree of exploitation, when using wet weight to measure the response of $D$. antarctica populations $(p<0.02)$.

\section{DISCUSSION}

It has been claimed that current ecological research on rocky intertidal habitats does not usually take into account human interference (Castilla \& Durán 1985, Durán et al. 1987). This could be due either to lack of awareness of its importance, or alternatively, to the knowledge that this factor is unimportant in a particular study site or ecosystem. Nevertheless, we believe that in either case human impact must not be overlooked. Indeed, recent review papers (Castilla 1986, Moreno 1986, Castilla \& Paine 1987) have raised the point of the key ecological role played by man as a top predator in some of these ecosystems. Most of the literature on this topic deals with human exploitation of primary consumer species (Branch 1975, Moreno et al. 1984, Oliva \& Castilla 1986), of sessile competitive dominant bivalves (Siegfried et al. 1985) or of top carnivorous predators (Castilla \& Durán 1985, Moreno et al. 1986). So far we have not found papers directly addressing the consequences of human exploitation on intertidal macroalgae at the population level or in the system as a whole. In this respect the Chilean coastline is unique because harvesting of rocky intertidal mac- roalgae is a traditional and commercially important activity (Joyce \& Santelices 1978, Santelices \& Lopehandia 1981, Santelices \& Avila 1985). For example, the intertidal bull-kelp Durvillea antarctica is traditionally consumed in Chile (Bory 1826, 1828 and Chamisso 1882 in Hay 1977, Guiler 1959, Castilla 1976, Santelices et al. 1980) and is readily harvested by shell fishermen (mariscadores) and visitors to the rocky intertidal.

In central Chile Durvillaea antarctica occurs at its northernmost geographical limit and, together with Lessonia nigrescens, comprises one of the most conspicuous features of the rocky intertidal (Santelices et al. 1980). Guiler (1959) predicted that $D$. antarctica should displace $L$. nigrescens by competition in areas with reduced human predation on the bull-kelp. He implied that in central Chile the selective removal of $D$. antarctica by humans prevents the competitive displacement of $L$. nigrescens. Santelices et al. (1980) tested Guiler's hypothesis in central Chile and contended that this prediction needed to be reconsidered. They concluded that water movement, rather than harvesting by humans, was the most important factor determining the outcome of this competitive interaction. Competitive displacement of $L$. nigrescens by $D$. antarctica was therefore likely to occur only at the intertidal-subtidal boundary of the most sheltered habitats of central Chile. Although we do not examine here the competition between these algae, our results show that $D$. antarctica can live in extremely exposed environments, such as small islands and the rocky shore of Las Cruces (as reported in New Zealand by Hay 1977; pers. obs. of J. C. Castilla at Anawhata, New Zealand). Our evaluation is that these shores are as exposed as some in the northern hemisphere where wave impact has been measured at $1000 \mathrm{~kg}$ per $\mathrm{m}^{-2}$ (Palumbi 1984, Ortíz \& Castilla unpubl.).

Our results demonstrate that the abundance of Durvillaea antarctica can be significantly reduced by 
human harvesting. We have shown, after a monitoring program of about $7 \mathrm{yr}$, that the population structure, density, and biomass of the bull-kelp increased significantly on rocky shores protected from mariscadores. Further, the size and biomass of D. antarctica plants increased significantly on adjacent non-harvested rocky shores as compared with harvested ones; likewise, the density of plants increased 2- to 4-fold.

It is interesting that the standing-crop of the bullkelp in ECIM non-harvested sites increased from about $100 \mathrm{~g}$ to between 200 and $300 \mathrm{~g} \mathrm{~m}^{-2}$ during the monitoring period (Fig, 3). These figures are similar to those reported for small islands which are less accessible to humans. Further, we found that the population structure and biomass of bull-kelp on islands were not significantly different between localities with fenced or non-fenced shores.

It should be pointed out that in more southern latitudes the plants could present different structural or ecological adaptations or show different growth rates: e.g. see results of Buschmann et al. (1984) for the relation diameter of holdfast $(\mathrm{DH})$ and wet weight for plants collected at Talcahuano, Chile $\left(36^{\circ} 40^{\prime} \mathrm{S}\right)$ as compared with ours. It is remarkable that the standing crop of Durvillaea antarctica reported for other geographic localities is much higher than that reported here. South \& Hay (1979) reported biomasses for D. antarctica of 15.0 to $20.4 \mathrm{~kg} \mathrm{~m}^{-2}$ and 10.1 to $15.1 \mathrm{~kg} \mathrm{~m}^{-2}$ for highly and moderately turbulent areas, respectively, of New Zealand, where there is an important industrial harvesting. Haxen \& Grindley (1985) reported biomasses of $38.82,161.69$ and $28.02 \mathrm{~kg} \mathrm{~m}^{-2}$, respectively, on exposed, sheltered and boulder-strewn continental sectors in Marion Island, South Africa. Lawrence (1986) documented the highest values of standing-crop at Kerguelen, $226 \mathrm{~kg} \mathrm{~m}^{-2}$. In the 2 latter localities (Marion and Kerguelen Islands) the harvesting of $D$. antarctica has not been reported.

Dayton (1985) reported wet biomasses of Durvillaea antarctica in Isla Knocker, Golfo de Trinidad, Chile $\left(50^{\circ} \mathrm{S}\right)$ of between 0.3 and $3.9 \mathrm{~kg} \mathrm{~m}^{-2}$. Undoubtedly our biomasses values are lower than those reported for other localities of southern Chile or the southern hemisphere. It must be kept in mind that our work was undertaken at the northern geographical limit of the species. Also, in population or management studies it is important to take into account the amount of time over which exploitation of the resource has occurred. The span of our study was about 4 to $7 \mathrm{yr}$ and the exploitation of Durvillaea in central Chile can be traced back at least $100 \mathrm{yr}$ (Bory 1826, 1828 and Chamisso 1882 in Hay 1977).

We believe that our results are indicative of at least 2 situations worthy of further study: (1) the human exploitation of Durvillaea antarctica is indeed an important factor that should be taken into account when population or community studies on this species are conducted; (2) special features of coastal geomorphology, such as small islands of difficult access, could represent important refuges or seeding grounds for adjacent shore populations of $D$. antarctica. We predict that relatively inaccessible exposed rocky shores or islands in central Chile should harbor higher biomasses of $D$. antarctica than rocky shores readily accessible to collectors. It is likely that the 'island seeding grounds' play a critical role on the adjacent rocky shores. These results bear important connections with future harvesting or management plans for this algae. Indeed, if areas could be set aside at regular intervals along the coast they would potentially increase yields at adjacent (harvestable) sites.

Acknowledgements. The authors acknowledge the help of our friends A. Jullian and B. Quinchalef who helped us with the field work. E. Ortíz made valuable statistical suggestions for the improvement of the final manuscript. Financial suport was given by the Universidad Católica de Chile, DIUC Project $63 / 84$, by the Organization of American States (OAS), Project 52 C 363 and FONDECYT, Project Nos. 86/1100 and 88/0432. We are also deeply grateful to Drs G. Branch, F. Jaksić, R. Ostfeld, and 3 anonymous referees for their critical review and suggestions. I. Aguirre helped us with the English presentation.

\section{LITERATURE CITED}

Anonymous (1987). Tablas de mareas de la costa de Chile. Instituto Hidrográfico de la Armada, Valparaiso

Araya-Vergara, J. G. (1982). Análisis de la localización de los procesos y formas predominantes de la línea litoral de Chile: observación preliminar. Inform. Geogr. Chile 29: $35-55$

Branch, G. M. (1975). Notes on the ecology of Patella conchlear and Cellana capensis and the effects of human consumption on limpet populations. Zool. Afr. 10: 75-85

Buschmann, A. (1982). Biología de Durvillaea antarctica (Phaeophyta, Durvilleales) en Chile centro-sur. Morfología y reproducción. Informe de unidad de investigación para optar al grado de Licenciado en Biología Marina. Universidad de Concepción, Concepción

Buschmann, A., Alveal, K., Romo, H. (1984). Biología de Durvillaea antarctica (Phaeophyta, Durvilleales) en Chile centro-sur. Morfología y reproducción. Mems. Asoc. Latinoam. Acuicult. 5: 399-406

Castilla, J. C. (1976). Parques y reservas maritimas chilenas. Necesidad de creación, probables localizaciones y criterios básicos. Medio Ambiente 2: 70-80

Castilla, J. C. (1981). Perspectivas de investigación en estructura y dinámica de comunidades intermareales rocosas de Chile central. II. Depredadores de alto nivel trófico. Medio Ambiente 5: 190-215

Castilla, J. C. (1986). ¿Sigue existiendo la necesidad de establecer parques y reservas marítimas en Chile? Ambiente y Desarrollo 2: 53-63

Castilla, J. C., Durán, R. (1985). Human exclusion from the intertidal zone of central Chile: the effects on Concholepas concholepas (Gastropoda). Oikos 45: 391-399 
Castilla, J. C., Paine, R. T. (1987). Predation and community organization on eastern Pacific, temperate zone, rocky intertidal shores. Revista Chilena de Historia Natural 60: 131-151

Castilla, J. C., Schmiede, P. (1979). Hipótesis de trabajo sobre la existencia de zonas marítimas tampones en relación a recursos marinos bentónicos (mariscos y algas) en la costa de Chile continental. In: Gallardo, V. A. (ed.) SeminarioTaller sobre desarrollo e investigación de los recursos marinos de la Octava Región, Chile. Universidad de Concepción, Concepción, p. 147-167

Conover, W. J. (1980). Practical nonparametric statistics, 2nd edn. John Wiley and Sons, New York

Dayton, P. K. (1985). The structure and regulation of some South American kelp communities. Ecol. Monogr. 55: $447-468$

Durán, R., Castilla, J. C., Oliva, D. (1987). Intensity of human predation on rocky shores at Las Cruces, central Chile. Environ. Conserv. 14: 143-149

Guiler, E. R. (1959). The intertidal ecology of the Montemar area, Chile. Pap. Proc. r. Soc. Tasmania 93: 165-183

Hay, C. H. (1977). A biological study of Durvillaea antarctica (Chamisso) Hariot and $D$. willana Lindauer in New Zealand. Ph. D. thesis, Univ. Canterbury, New Zealand

Hay, C. H. (1979a). Some factors affecting the upper limit of the southern bull-kelp Durvillaea antarctica (Chamisso) Hariot on two New Zealand shores. J. r. Soc. N. Z. 9: 279-289

Hay, C. H. (1979b). Nomenclature and taxonomy within the genus Durvillaea Bory (Phaeophyceae: Durvilleales Petrov). Phycologia 18: 191-202

Hay, C. H. (1979c). Growth, mortality, longevity and standing crop of Durvillaea antarctica (Phaeophyceae) in New Zealand. In: Jensen, A., Stein, J. R. (eds.) Proceedings of the IXth International Seaweed Symposium. Santa Barbara, California, p. 97-104

Hay, C. H., South, G. R. (1979). Experimental ecology with particular reference proposed to commercial harvesting of Durvillaea antarctica (Phaeophyta, Durvilleales) in New Zealand. Botanica mar. 23: 431-436

Haxen, P. G., Grindley, J. R. (1985). Durvillaea antarctica production in relation to nutrient cycling at Marion Island. In: Siegfried, W. R., Condy, P. R., Laws, R. M. (eds.) Antarctic nutrients cycles and food webs. Springer-Verlag, Berlin, p. 637-640

Hockey, A. R., Bosman, A. L. (1986). Man as an intertidal predator in Transkei: disturbance, community convergence and management of a natural food resource. Oikos 46: $3-14$

Joyce, L. \& B. Santelices. (1978). Producción y explotación de algas en Chile (1967-1975). Biol. Pesq. 10: 3-26

Lawrence, J. M. (1986). Proximate composition and standing crop of Durvillaea antarctica (Phaeophyta) in the Bay of Morbihan, Kerguelen (South Indian Ocean). Mar. Ecol. Prog. Ser. 33: 1-5

Moreno, C. A. (1986). Un resumen de las consecuencias ecologicas de la exclusión del hombre en la zona intermareal de Mehuín - Chile. Estud. Oceanol. 5: 59-66

Moreno, C. A., Lunecke, K. N., Lpez, M. I. (1986). The response of an intertidal Concholepas concholepas (Gastropoda: Muricidae) to protection from man in southern Chile and its effects on benthic sessile assemblages. Oikos 46: 359-364

Moreno, C. A., Sutherland, J. P., Jara, F. H. (1984). Man as a predator in the intertidal zone of southern Chile. Oikos 42: $155-160$

Ojeda, F. P., Santelices, B. (1984). Ecological dominance of Lessonia nigrescens (Phaeophyta) in central Chile. Mar. Ecol. Prog. Ser. 9: 83-91

Oliva, D., Castilla, J. C. (1986). The effects of human exclusion on the population structure of key-hole limpets Fissurella crassa and F. limbata on the coast of central Chile. P.S.Z.N.I. Mar. Ecol. 7: 201-217

Paine, R. T. (1966). Food web complexity and species diversity. Am. Nat. 100: 65-75

Paine, R. T. (1971). A short-term experimental investigation of resource partitioning in a New Zealand rocky intertidal habitat. Ecology 52: 1096-1106

Palumbi, S. R. (1984). Measuring intertidal wave forces. J. exp. mar. Biol. Ecol. 81: 171-179

Santelices, B. (1981). Perspectivas de investigación en estructuras y dinámicas de comunidades intermareales rocosas de Chile central. I. Cinturones de macroalgas. Medio Ambiente 5: 175-189

Santelices, B., Avila, M. (1985). Bases biológicas para maximizar la cosecha del 'luche' (Porphyra columbina, Montagne) en Chile central. In: Westermeir, R. (ed.) Actas del II Congreso de Algas Marinas Chilenas. Universidad Austral de Chile. Valdivia, p. 201-211

Santelices, B., Cancino, J., Montalva, S., González, E. (1977). Estudios ecológicos en la zona costera afectada por contaminación del 'Northern Breeze'. II. Comunidades de playas de rocas. Medio Ambiente 2: 65-83

Santelices, B., Castilla, J. C., Cancino, J., Schmiede, P. (1980). Comparative ecology of Lessonia nigrescens and Durvillaea antarctica (Phaeophyta) in central Chile. Mar. Biol. 59: $119-132$

Santelices, B., Lopehandía, J. (1981). Chilean seaweed resources: a quantitative review of potential and present utilization. In: Levring, T. (ed.) Proceedings Xth International Seaweed Symposium. Walter de Gruyter, New York, p. $725-730$

SAS (1986). SAS user's guide: statistics, 1986 edn. SAS Institute Inc., Cary, N. Carolina

Siegfried, W. R., Hockey, P. A. R., Crowe, A. A. (1985). Exploitation and conservation of a brown mussel stock by coastal people of Transkei. Environ. Conserv. 12: 303-307

Sokal, R. R., Rohlf, F. J. (1981). Biometry. 2nd edn. W. H. Freeman Press, San Francisco

South, G. R., Hay, C. H. (1979). Influence of wave action and latitude on morphology and standing crop of New Zealand Durvillaea antarctica (Chamisso) Hariot (Phaeophyta, Durvilleales). J. r. Soc. N. Z. 9: 289-296 